\title{
The Executive Compensation Incentive Effectiveness Research of Listed Company of Beijing
}

\author{
Wenqi $\mathrm{Li}^{1, \mathrm{a}}$, Zengmin Wang ${ }^{2, \mathrm{~b}}$,Xiaofan $\mathrm{Xu}^{2, \mathrm{c}}$ and Yujing $\mathrm{Liu}^{2, \mathrm{~d}}$ \\ ${ }^{1}$ Beijing University of Posts and Telecommunications, Beijing 500381, China \\ ${ }^{2}$ Beijing University of Posts and Telecommunications, Beijing 500381, China \\ ${ }^{3}$ Beijing University of Posts and Telecommunications, Beijing 500381, China \\ ${ }^{4}$ Beijing University of Posts and Telecommunications, Beijing 500381, China \\ aliwenqi1220@126.com, bwangzengmin@vip.sina.com, c2543242738 @qq.com, \\ d1557941452@qq.com
}

Li Wenqi is a undergraduate student majoring in accouting from Beijing University of Posts and Telecommunications, Wang Zengmin is a associate professor and Xu Xiaofan and Liu Yujing are both undergraduater students.

*Wenqi Li

Keywords: Executive compensation incentive, effectiveness, hysteresis, economic inertia.

\begin{abstract}
With the separation of the ownership and management right of modern enterprise, asymmetric information between management and owner leads to the principal-agent contradiction. At present, the monetary compensation incentive and equity compensation incentive are regarded as the most direct and effective means to solve the agency problem, and its incentive effect has become the core of corporate governance, which is widely concerned by academic and practical circles. We take the data of Beijing listed companies from 2011 to 2015 as the sample, and then compared the effectiveness of the two incentive means through the panel analysis while considering the lag effect of incentive measures. We found that the monetary compensation incentive and equity compensation incentive are both related to the performance of listed companies in Beijing, and there is a lag; the effect of monetary compensation incentive decreases as time moved which is more likely to lead executives to make short-term profit behaviors. Then we introduce the lagging indicators of performance into the model to control the economic inertia, and found that the monetary compensation incentive is more effective than the equity compensation incentive means by iteration, which has a more significant impact on the executive behavior.
\end{abstract}

\section{Introduction}

Because of the separation of ownership and management right of modern enterprise, the management knows more about the company's operating status than shareholders, and the asymmetric information brings more rent-seeking space for managers, such as the improvement of social status and the establishment of reputation, which makes the company's goal cannot be effectively realized, instead, the agency cost is increased. The principal-agent theory believes that the reasonable incentive system can drive the unity of management's goals and shareholders' goals, in return to reduce the agency cost and effectively inspire management to achieve the maximization of enterprise value. It is the most direct and effective way to solve the contradiction between managers and owners. However, at present, the exposure of Ping An's out-sized pay in 2008 in China as well as occupy the Wall Street occurred in America in 2011 makes executive compensation incentive controversial. When the executive compensation is linked to the corporate performance, whether it plays an incentive role or become an executive tool, becomes the core issue of corporate governance.

At present, the most widely used executive incentives means by domestic and foreign listed companies are monetary compensation incentive which is mainly wage income for short-term incentive, and equity compensation incentive for long-term incentives (Ping Wang, 2014). However, 
there is also a controversy about the incentive effect of these two incentive means in the academic circles. Murphy (1985) thinks that the corporate performance significantly affects the monetary compensation of executive, and in turn the executive will work hard to improve personal salary by improving the corporate performance from the perspective of rational man, thus the monetary compensation incentive has positive effects on improving corporate performance. The research of domestic Zengquan Li ( 2000 ), Gang Wei ( 2000 ), Zhang Juan ( 2008 ) also support the positive promotion of monetary compensation incentive. However, Jianping Hou ( 2014 ) and Yu Fusheng ( 2013 ) think this brings a motivation for executives to beautify the statements. And after comparing the effects of executive management compensation incentive on corporate performance and earnings management, Jianping Hou believes that the monetary compensation incentive is positively correlated with earnings management, but the incentive effect is not good; After comparing the growth of the pay gap between management and staff with the improvement of corporate performance, Yu Fusheng finds that the performance decreased when the pay gap increased. And then he combines the finding with earnings management, finds that executives usually enhance report performance by modifying earnings management and widening pay gap, in other words, the monetary compensation incentives doesn't work. Despite there is a controversy, monetary compensation incentive is still the most widely used among listed companies in China, which call for our high attention.

The equity incentive means has been widely used abroad, because shareholders hope to attract and retain those special talents who have less risk aversion and higher desire to display their ability. There is no deterministic conclusion on domestic research of the incentive of equity compensation, but most of scholars think the incentive effect is not obvious. On the one hand, scholars think the company that performs the incentive of equity compensation is still a minority, which affects the performance of the incentive effect of equity compensation to some extent ( Zengquan Li, 2000; Gang Wei, 2000 ); On the other hand, due to the regulatory system of listed companies in China is not perfect, and it is easily influenced by the gray operations such as insider trading, the equity compensation incentive effect is poor ( Bin Gu, Liye Zhou, 2007 ). However, the above paper does not consider the lag impact of equity compensation incentive, and Jianping Hou found that equity compensation incentive has no effect on company earnings management by introducing the equity compensation incentive hysteresis, but has its desirability as a long-term incentive means. At the same time, with the introduction of Measures for the administration of information disclosure of listed companies and the implementation of incentive management of equity compensation of listed companies, the political environment of the implementation of equity compensation of listed companies is more perfect, the long-term impact of equity compensation incentive is also worthy of our attention.

In the study of the effectiveness of executive compensation incentive, scholars generally start from two aspects. The first one uses the compensation incentive intensity as explanatory variable and the company performance as the explanatory variable to study the direct impact of the incentive intensity on the performance of the company, and the coefficient of incentive intensity index represents the incentive intensity. Rosen ( 1990 ), Zengquan Li ( 2000 ) and Renjun Zhou ( 2012 ) also used this method. The papers of Ling Hu ( 2012 ), Ping Wang ( 2014 ), and Song Tang ( 2014 ) inversely used the executive compensation as the explained variables and performance indicators as explanatory variables, measuring the incentive effect according to the correlation between performance and compensation, and find the greater the correlation, the better the performance. This paper uses the first method because it can be more intuitive to observe the incentive effects. However, due to the existence of economic inertia, the accumulation of previous business will affect the current situation, and the influence of corporate performance cannot be ignored, so our paper deems that the early operating results should be controlled in measuring the effectiveness of executive compensation incentive.

In addition, shareholders will also measure the matching degree of executive pay and corporate performance, and the status of previous executive compensation will have an impact on the board of directors deciding dismissals or compensation adjustments, thus bringing firing pressure on executives ( Jensen, 1990 ). In order to maintain social status, reputation or some other needs, 
management will also try to avoid layoffs and then work hard to improve company's performance, thus both current pay and previous pay will have incentives for future performance. Therefore, in the study of the effectiveness of executive compensation incentive, we should consider the lag of incentive effect, and introduce the lag term in the model to make the conclusion more reliable. At the same time, it has also found that the size of the company, the size of the board of directors, the size of the board of supervisors and the proportion of state-owned shares will also affect executive compensation incentive effect, so this paper deems that the variables need to be controlled when building the model.

Based on the above, we start from the effectiveness of monetary compensation incentive and equity compensation incentive in this paper, and we choose the listed companies in Beijing from 2011 to 2015 as samples, and measure the incentive effect of monetary compensation incentive and equity compensation incentive at the same time. And on the basis of the introduction of lag term, we make a more comprehensive study of the effectiveness of two incentives above.

\section{Design of Executive Compensation Incentive Effectiveness Model}

Gang Wei (2000 ) selected 813 A-Share listed companies in 1998 as samples, and select the weighted average Rate of Return on Common Stockholders' Equity ( ROE ) as the measurement standard of the company performance, as well as using the total annual compensation ( $\mathrm{AC}$ ) and executive shareholding ratio ( MSR ) as the incentive index. Through testing the linear regression equations: $\mathrm{ROE}=\alpha+\beta * \mathrm{ROM}+\varepsilon$ and $\mathrm{ROE}=\alpha+\beta * \mathrm{SOM}+\varepsilon$, he finds that there is no significant positive correlation between executive monetary compensation and operating performance, and the incentive effect of equity compensation is not played. However, there this is only data from 1998 in his model, without considering the hysteresis effects of incentive, therefor the conclusion may be deviated from the real situation. At the same time, it may lead to the distortion of the conclusion without building a nonlinear model test because in Gang Wei's model, he thinks that the incentive means and corporate performance are linear. Renjun Zhou (2012) makes up for this loss in his research. Through a quadratic equation and a univariate cubic equation, he finds that the linear equation fitting is the optimal, and that the compensation incentive is linear with the company's compensation. In this paper, we follow his point, only consider the linear relationship between these two incentive methods and corporate performance in the model .

The model of Jingjing Zuo and Yuejun Tang ( 2010 ) uses rate of return on common stockholders' equity (ROE) and gross profit ratio (GPR) as the explained variable (DEP), uses total annual remuneration of senior management ( MTC), average remuneration of senior management ( MAC ), total remuneration of the top three directors ( $\mathrm{T}_{3} \mathrm{DC}$ ) and top three top executive compensation ( $\mathrm{T}_{3} \mathrm{MC}$ ) comprehensively measure the level of salary incentive. At the same time, they control year, industry, company size, financial leverage as control variables ( $\mathrm{BCV}$ ). The basic model is: $\mathrm{DEP}=\mathrm{B} 0+\sum_{i=1}^{N} B i E V i+\sum_{i=1}^{N} B i C V i$, and in the model, they process the performance indicators for the lag issue $(t+1)$ and the two phase lag $(t+2)$. The study finds that executive compensation incentive is positively related to corporate performance and has hysteresis effect. This model considered the hysteresis of the incentive, the conclusion is more real. However, the model confused the monetary compensation incentive and the equity compensation incentive, without considering the differences between them. In fact, the monetary compensation incentive has more short-term incentive effects for executives, while equity compensation incentive is long-term incentive means, so there must be difference between them. Therefore the model should be revised to distinguish these two incentives.

Among the papers that believe compensation incentive has increased the agency cost, Jianping Hou, Rongrong Hui( 2014 ) calculate the manipulated accruals ( DA ) to measure the earnings management level. And they mesure the incentive effects by comparing the monetary compensation incentive level (Pay) based on the logarithm of total executive compensation and the equity compensation incentive level ( Stock ) in executive ownership on the impact of DA and return on total assets ( ROA ). At the same time, the paper also process DA and Pay for the lag issue and lag two periods, found that the current executive incentive has no significant relationship with current 
earnings management, and the early executive incentive significantly affects the current earnings management, but the previous equity compensation incentive does not affect, so that the executive incentive has intertemporal influence, and promote executives to manipulate the report. In the study of Yuhui Wu and Shinong $\mathrm{Wu}(2010)$ ), using management fee rate and asset turnover to represent the agency cost, get a similar conclusion. Listed models use ROA as a performance indicator without considering whether the performance evaluation index is appropriate.

On the basis of the existing models, we select return on total assets ( ROA ), rate of return on common stockholders' equity (ROE), and earnings per share ( EPS ) as indicators of performance evaluation. And we measure the effectiveness of executive compensation incentives from three aspects, including the profitability of the company's total assets, the value created by the manager for the owner and earnings per share.

At the same time, due to the top three executives represents management compensation level almost equals the total compensation, thus in our paper, we select the total compensation for the top three executives disclosed in the annual report of listed companies as the total executive compensation to measure the monetary compensation incentive strength according to the existing literature ( Qingquan Xin, 2007; Junxiong Fang, 2009; Yuhui Wu, Shinong Wu, 2010 and so on), and then $\log$ on it to eliminate the multicollinearity and guarantee the normality of variables. In addition, we use the executive shareholding (executive shareholding / total issue number ) to represent the incentive strength of equity compensation .

Based on this, we construct the following model in this paper:

ROAt $=\alpha 1+\mathrm{a} 1 * \mathrm{LNTCt}+\mathrm{a} 2 * \mathrm{LNTCt}-1+\mathrm{a} 3 *$ LNTCt-2+a4*LNTCt-3+b5*MSRt+b6*MSRt-1+b7*MSR

$$
\mathrm{t}-2+\mathrm{b} 8 * \text { MSRt }-3+\mathrm{c} * \text { LNSIZEt+d*DBSt+e } * \text { SBSt+f*GOVt }
$$

ROAt $=\alpha 1+\mathrm{a} 1 * \mathrm{LNTCt}+\mathrm{a} 2 * \mathrm{LNTCt}-1+\mathrm{a} 3 * \mathrm{LNTCt}-2+\mathrm{a} 4 * \mathrm{LNTCt}-3+\mathrm{b} 5 *$ MSRt+b6*MSRt-1+b7*MSR

$$
\text { t-2+b8 *MSRt-3+c*LNSIZEt+ d*DBSt+ e*SBSt+ f*GOVt+b13*ROAt-1 }
$$

$\mathrm{ROEt}=\alpha 1+\mathrm{a} 1 * \mathrm{LNTCt}+\mathrm{a} 2 * \mathrm{LNTCt}-1+\mathrm{a} 3 * \mathrm{LNTCt}-2+\mathrm{a} 4 *$ LNTCt-3+b5*MSRt+b6*MSRt-1+b7*MSRt

$$
-2+\mathrm{b} 8 * \text { MSRt-3+c*LNSIZEt+d*DBSt+e*SBSt+f*GOVt }
$$

ROEt $=\alpha 1+\mathrm{a} 1 * \mathrm{LNTCt}+\mathrm{a} 2 * \mathrm{LNTCt}-1+\mathrm{a} 3 * \mathrm{LNTCt}-2+\mathrm{a} 4 * \mathrm{LNTCt}-3+\mathrm{b} 5 *$ MSRt+b6*MSRt-1+b7*MSRt

-2+b8 *MSRt-3+c*LNSIZEt+ d*DBSt+ e*SBSt+ f*GOVt+b13*ROEt-1

EPSt $=\alpha 1+a 1 *$ LNTCt+a2*LNTCt-1+a3*LNTCt-2+a4*LNTCt-3+b5*MSRt+b6*MSRt-1+b7*MSRt

$-2+\mathrm{b} 8 *$ MSRt $-3+\mathrm{c} * \mathrm{LNSIZEt}+\mathrm{d} * \mathrm{DBSt}+\mathrm{e}^{*} \mathrm{SBSt}+\mathrm{f} * \mathrm{GOVt}$

EPSt $=\alpha 1+\mathrm{a} 1 * \mathrm{LNTCt}+\mathrm{a} 2 * \mathrm{LNTCt}-1+\mathrm{a} 3 * \mathrm{LNTCt}-2+\mathrm{a} 4 * \mathrm{LNTCt}-3+\mathrm{b} 5 *$ MSRt+b6 $*$ MSRt-1+b7*MSRt

$$
-2+b 8 * \text { MSRt }-3+c * \text { LNSIZEt+d*DBSt+e*SBSt+f*GOVt+b13 EPSt-1 }
$$

Table 1. Variables

\begin{tabular}{c|l|c|l}
\hline & \multicolumn{1}{|c|}{ name } & symbol & \multicolumn{1}{c}{ explanation } \\
\hline \multirow{2}{*}{$\begin{array}{c}\text { Explain } \\
\text { ed } \\
\text { variable } \\
\text { s }\end{array}$} & Return on Total Assets & ROA & $\begin{array}{l}\text { Net profit/(total assets at the } \\
\text { beginning of the period + total } \\
\text { assets at the endning of the } \\
\text { period }) / 2)\end{array}$ \\
\cline { 2 - 4 } & Stockholders' Equity & ROE & $\begin{array}{l}\text { Net profit/(( owner equity at the } \\
\text { beginning of the period +owner } \\
\text { equity at the endning of the } \\
\text { period }) / 2)\end{array}$ \\
\cline { 2 - 4 } & Earnings Per share & EPS & $\begin{array}{l}\text { Net profit / Weighted average } \\
\text { number of ordinary shares }\end{array}$ \\
\hline
\end{tabular}




\begin{tabular}{|c|c|c|c|}
\hline \multirow{2}{*}{$\begin{array}{c}\text { Explana } \\
\text { tory } \\
\text { variable } \\
\mathrm{s}\end{array}$} & Remuneration & LNTC & $\begin{array}{l}\text { The natural logarithm of the sum } \\
\text { of the top three executive } \\
\text { compensation }\end{array}$ \\
\hline & $\begin{array}{l}\text { Shareholding rate of } \\
\text { management }\end{array}$ & MSR & $\begin{array}{l}\text { Executive shares / Total issued } \\
\text { shares }\end{array}$ \\
\hline \multirow{4}{*}{$\begin{array}{l}\text { Controll } \\
\text { ed } \\
\text { variable } \\
\text { s }\end{array}$} & Enterprise scale & $\begin{array}{c}\text { LNSIZ } \\
\text { E }\end{array}$ & Logarithm of total assets \\
\hline & Board size & DBS & Number of directors \\
\hline & Board of supervisors scale & SBS & Number of supervisors \\
\hline & State-owned shareholding ratio & GOV & $\begin{array}{l}\text { State-owned shareholding / total } \\
\text { issued shares }\end{array}$ \\
\hline
\end{tabular}

\section{Data Sources and Descriptive Statistics}

The data in this paper is mainly from the CSMAR Solution, Wind information and related annual reports of listed companies from 2011 to 2015. At the same time, to ensure the validity of the data, we select the data according to the following standards. (1) Retaining only relevant data of A shares of listed companies. (2) Eliminating relevant data of ST, *ST listed companies and those that have been delisted.(3) Eliminating data of listed companies with missing information and incomplete data and those listed in recent years. Finally, a total of 830 samples are obtained.

Descriptive statistics of the 165 listed companies in Beijing (830 samples in a total of five years) are shown in Table below. The highest monetary compensation of managers can reach almost 15 million yuan, while the lowest is only 200 thousand yuan. It is obvious that the gap among executive compensation in different listed company is great. According to the average value, we can see that there is a discrete law of left skewed distribution, that is to say, more than half of the company's monetary pay is below the average number which is at low income levels. Look at the proportion of executive shareholding we can find that the largest shareholding ratio reached $71.4 \%$, while there is still no shareholding ratio in some companies. When the data were further process, we also found that in Beijing, a total of 166 listed companies, only 36 companies have executives holdings, other companies did not achieve equity incentive for executives. Overall, the proportion of executive ownership shows a clear left skewness, which shows that the listed companies in Beijing have very serious deficiencies in the equity incentive. In general, in terms of compensation, there is a gap between the compensation of the companies in Beijing. At present, most companies still use monetary compensation incentive.

From the company's scale indicators (SIZE, DBS, SBS) we can find that there is difference in the size of these 830 listed companies, but the gap is not obvious. This also showed a left skewed distribution. The number of largest company's board of directors can reach 17, and those small companies almost have no board or board of directors. Generally speaking, there is no big difference in the size of these 830 companies, which is conducive to control the scale indicators in the study of compensation.

Table 2. Descriptive statistics of variables

\begin{tabular}{l|l|l|l|l|l}
\hline variables & Maximum & Minimum & Median & Average & Standard deviation \\
\hline LNTC & 16.52263 & 12.16718 & 14.46958 & 14.48738 & 0.62362 \\
\hline TC & 14986100 & 192370.70 & 1922350 & 2391488 & 1762310 \\
\hline MSR & 0.714072 & 0 & 0.000037 & 0.0609 & 0.135822 \\
\hline LNSIZE & 30.67717 & 18.16238 & 21.98621 & 22.6035 & 2.200724 \\
\hline SIZE & $2.1 * 10^{13}$ & 77236597 & $3.54 * 10^{9}$ & $4.49^{*} 10^{11}$ & $2.37 * 10^{12}$ \\
\hline DBS & 17 & 0 & 9 & 9.183133 & 2.395252 \\
\hline SBS & 14 & 1 & 3 & 3.963855 & 1.673218 \\
\hline GOV & 0.82663 & 0 & 0 & 0.063616 & 0.159919 \\
\hline
\end{tabular}




\section{Empirical Results and Analysis}

4.1The Impact of Monetary Compensation Incentive on Executives. As we can see from the data in Table below, in the model based on ROA and ROE as performance index, monetary compensation incentive index (LNTC, LNTC $_{\mathrm{t}-1}, \mathrm{LNTC}_{\mathrm{t}-2}$ ) pass the significant test, and the coefficient is positive, indicating that monetary compensation is positively correlated with corporate performance, in other words, monetary incentive has a positive incentive effect on executives, and the incentive effect is hysteretic. At the same time, comparing the results of this two models, the monetary compensation incentive intensity is significantly enhanced in the model of ROE as the performance index. Thus we think that after the company implementing monetary compensation for executives, managers will work hard for increasing the income of the owner of company, while for external creditors, they just want to maintain their good lending relationship rather than strive for the early realization of creditors' interest. The result confirms that white profit phenomenon is eased.

In the regression results of the model that EPS works as a performance index, there is no significant relationship between monetary compensation incentive and earnings per share, and the phase lag two period of total monetary compensation and the lag three period of the total amount of monetary compensation coefficient is negative, and there is a perverse incentives.

From the point of the timeliness of incentive, four consecutive period of monetary compensation levels will affect the current executive compensation, but from the point of incentive effect, the incentive effect weakened as time goes on, which means the current incentive effect is the best, and the previous' is worse than it. The results shows that the executive compensation incentive is a long-term impact. However, executives will pay more attention to the current short-term decision-making for the increase in the benefits it brings. Therefore, shareholders should make monetary compensation incentive plan in view of long-term effect, and let executives aware of the long-term impact of their behavior in order to avoid short-term profit behavior.

4.2 The Impact of Equity Incentive on Executive Behavior. As shown in Table below, in the model which ROA works as the performance index, the equity incentive indicators (MSR MSR $_{\mathrm{t}-1 \text {, }}$ MSRT $_{\mathrm{t}-2}, \mathrm{MSR}_{\mathrm{t}-3}$ ) pass the significant test proving that the equity incentive compensation is also lagging behind. At the same time, in the model (1) and model (3), the coefficients of equity compensation incentive index are positive, indicating that the equity incentive will have a positive effect on corporate performance.

Considering the regression result from the perspective of timeliness, we find the result is different from the degressive incentive effect of monetary compensation incentive. Each stage of the effect of the equity incentive for executives in the current phase is almost the same. It shows that executives of listed companies in Beijing not only pay attention to the current incentive level, but also pay attention to the impact of the current behavior in the future which in return avoids the short-term behavior. The long term incentive effect of the wquity incentive is better.

On the basis of regression results of the model (1) (3) (5), we think that, at present, monetary compensation incentive is still more significantly effective in the listed companies of Beijing, but the equity incentive can avoid the short-term behaviors of executives, so the listed company should also gradually begin to implement equity incentive.

4.3 Comparison of Two Incentive Methods. From the above analysis we can see that the monetary compensation incentive has a significant positive effect on the behavior of executives. Equity incentive also has a positive incentive, but the effect is not significant. In order to get a further conclution of the effectiveness of this two types of incentives, we introduced the lag of the performance variables on the basis of the model (1) to control the role of economic inertia. Through the compersion of the regression results of model (1) and model (2), we find the effect of equity incentive is slight enhanced while taking into the spontaneous increase of the operating results of the company. While monetary compensation incentive effect ${ }^{\prime}$ change is little overall, but the impact of the current and previous period of total compensation on Corporate performance increase. In the 
process of enterprise management, monetary compensation incentive is more effective as a short-term incentive, and equity incentive is more appropriate as a long-term incentive.

After the introduction of lagging performance indicators, we continue to iterate on the model: ROAt $=\alpha 1+a 1 *$ LNTCt+a $2 *$ LNTCt-1+a3*LNTCt-2+a $4 *$ LNTCt-3+b5*MSRt+b6*MSRt-1

$+\mathrm{b} 7 *$ MSRt-2+b8 *MSRt-3+c*LNSIZEt+ d*DBSt+ ${ }^{*}$ SBSt+ $\mathrm{f}^{*} \mathrm{GOVt}+\beta *$ ROAt -1

ROAt-1= $\alpha 1+\mathrm{a} 1 *$ LNTCt-1+a2*LNTCt-2+a3*LNTCt-3+a4*LNTCt-4+b5*MSRt-1+b6*MSRt-2 +b7*MSRt-3+b8 *MSRt-4+c*LNSIZEt-1+ d*DBSt-1+ e*SBSt-1+ f*GOVt-1+ $\beta$ *ROAt-2

ROAt-2= $\alpha 1+\mathrm{a} 1 *$ LNTCt-2+a3*LNTCt-3+a3*LNTCt-4+a4*LNTCt-5+b5*MSRt-2+b6*MSRt-3 + b7*MSRt-4+b8 *MSRt-5+c*LNSIZEt-2+ $\quad$ d*DBSt+ $\quad e^{*}$ SBSt-2+ $\quad f^{*}$ GOVt-2+ $\beta$ *ROAt-3

Bring ( 8 ) to ( 7 ):

$$
\begin{aligned}
& \mathrm{ROAt}=\alpha 1+\mathrm{a} 1 * \mathrm{LNTCt}+(\mathrm{a} 2+\beta * \mathrm{a} 1) * \mathrm{LNTCt}-1+(\mathrm{a} 3+\beta * \mathrm{a} 2) * \mathrm{LNTCt}-2+(\mathrm{a} 4+\beta * \mathrm{a} 3) * \mathrm{LNTCt}-3+ \\
& \beta * \mathrm{a} 4 * \text { LNTCt }-4+\mathrm{b} 5 * \text { MSRt+ }(\mathrm{b} 2+\beta * \mathrm{~b} 1) * \text { MSRt } 1+(\mathrm{b} 3+\beta * \mathrm{~b} 2) * \text { MSRt }-2+（ \mathrm{~b} 4+\beta \\
& \text { *b3*MSRt-3+ } \beta * \mathrm{~b} 4 * \text { MSRt }-4+\beta * \mathrm{c} * \text { LNSIZEt }-1+\mathrm{c} * \text { LNSIZEt }+\beta * \mathrm{~d} * \text { DBSt }-1+\mathrm{d} * \text { DBSt+ } \\
& \beta \quad * \mathrm{e}^{*} \mathrm{SBSt}-1+\mathrm{e}{ }^{*} \mathrm{SBSt}+\quad \beta \quad * \mathrm{f} * \mathrm{GOVt}-1+\quad \mathrm{f} * \mathrm{GOVt}+\quad \beta \quad{ }^{2 * \mathrm{ROAt}}-2
\end{aligned}
$$

Bring ( 9) to ( 10):

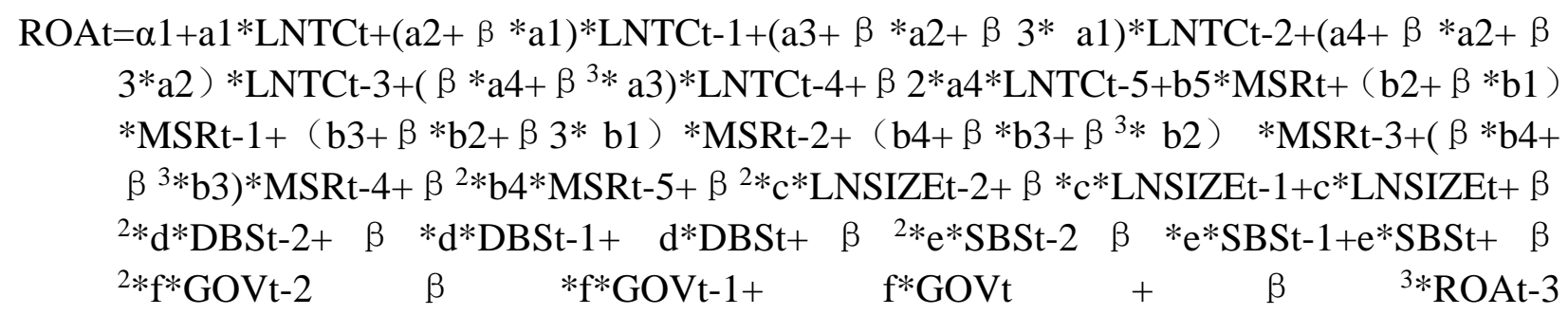
(11)

The former coefficients of the monetary compensation performance indicators $\left(\mathrm{LNTC}_{\mathrm{t}}, \mathrm{LNTC}_{\mathrm{t}-1}\right.$, $\left.\mathrm{LNTC}_{\mathrm{t}-2}, \mathrm{LNTC}_{\mathrm{t}-3 \ldots} \ldots\right)$ and equity incentive indicators $\left(\mathrm{MSR}_{\mathrm{t}}, \mathrm{MSR}_{\mathrm{t}-1}, \mathrm{MSR}_{\mathrm{t}-2}, \mathrm{MSR}_{\mathrm{t}-3 \ldots)}\right.$ ) are summed and composed of two groups of numbers, $\left\{a_{1}, a_{1}+a_{2}+\beta * a_{1}, a_{1}+a_{2}+\beta * a_{1}+a_{3}+\beta * a_{2}+\beta 3 * a_{1}, a_{1}+\right.$ $\left.a_{2}+\beta * a_{1}+a_{3}+\beta * a_{2}+\beta^{3 *} a_{1}+a_{4}+\beta * a_{2}+\beta{ }^{3 *} a_{2} \ldots\right\}\left\{b_{1}, b_{1}+b_{2}+\beta * b_{1}, b_{1}+b_{2}+\beta * b_{1}+b_{3}+\beta * b_{2}+\beta\right.$ $\left.3 * b_{1}, b_{1}+b_{2}+\beta * b_{1}+b_{3}+\beta * b_{2}+\beta{ }^{3 *} b_{1}+b_{4}+\beta * b_{2}+\beta{ }^{3 *} b_{2} \ldots\right\}$ and the convergence value is calculated, which represents the monetary compensation incentive intensity and the equity incentive intensity. The results show that in the model of ROA as the performance index, the coefficient of monetary pay incentive converges to 0.13 . Due to the executive compensation the log processing, the coefficient of $\mathrm{LNTC}_{\mathrm{t}} \mathrm{a}=\triangle \mathrm{ROA} / \triangle \mathrm{TC}=1 / \mathrm{TC}, \triangle \mathrm{ROA}=\mathrm{a}^{*}(\triangle \mathrm{TC} / \mathrm{TC})$, namely ROA executive monetary compensation every $1 \%$ growth will drive the growth of corporate performance 0.13 units, which means that if the executive's salary grow of 1 per unit, it will promote the corporate performance of 13 unit. And equity incentive coefficient (b) approach in 0.01 , and because of $b=\triangle$ $\mathrm{ROA} / \triangle \mathrm{MSR}, \triangle \mathrm{ROA}=\mathrm{b}^{*} \triangle \mathrm{MSR}$, if the proportion of managerial ownership increases 1 units, it will take 0.01 units of the company performance growth. It can be seen that the effect of monetary compensation incentive is better than equity incentive.

Use the same method on ROE and EPS performance index model of convergence analysis. In the model of $\mathrm{ROE}$ as the dependent variable, the coefficient of monetary incentive index converges to 0.172 , the coefficient of equity incentive index converges to 0.00402 , and the conclusion is same with ROA as the performance index that the effect of monetary incentive is better than equity incentive. 
In the model of EPS as the performance index, the convergence values of the two incentive methods are 0.059 and 0.0013 , which is also consistent with the conclusion above.

Table 3. Regression results

\begin{tabular}{|c|c|c|c|c|c|c|}
\hline 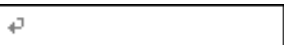 & \multicolumn{2}{|l|}{$\mathrm{ROA}$} & \multicolumn{2}{|l|}{ ROE } & \multicolumn{2}{|l|}{ EPS } \\
\hline $\mathrm{C}$ & $-2.626123^{* * *} *$ & $-2.637869 * * * 4$ & $-3.662266^{* *}$ & $-3.406314 * 8$ & 3.346918 & 5.679270 \\
\hline LNTCt & $0.050828 * * *$ & $0.053436 * * *$ & $0.100453 * * * 4$ & $0.103607 * * *$ & 0.068590 & 0.086590 \\
\hline LNTC $_{t-1}$ & $0.045826 * *$ & $0.051689 * * *$ & $0.072540 *$ & $0.089465 * *$ & 0.042219 & -0.013664 \\
\hline LNTC $_{t-2}$ & $0.034234 * *$ & $0.033813 * *$ & $0.051099 *$ & $0.045975 * *$ & -0.140618 & -0.160777 \\
\hline LNTC $_{t-3}$ & 0.023795 & 0.016710 & 0.020969 & -0.010293 & -0.186619 & -0.230829 \\
\hline $\mathrm{MSR}_{\mathrm{t}}$ & $0.153418 *$ & $0.163164 *$ & 0.149988 & 0.189115 & 0.404166 & 0.571402 \\
\hline $\mathrm{MSR}_{\mathrm{t}-1}$ & $0.169605 * *$ & $0.168009 * *$ & 0.178136 & 0.178256 & -0.133635 & -0.130817 \\
\hline $\operatorname{MSR}_{\mathrm{t}-2}$ & $0.155256 * *$ & $0.165068 * * *$ & 0.156186 & 0.170466 & -0.116419 & 0.010787 \\
\hline $\mathrm{MSR}_{\mathrm{t}-3}$ & 0.156309 & 0.169911 & 0.211508 & 0.213672 & -0.524911 & -0.373693 \\
\hline LNSIZE & 0.013723 & 0.014191 & $-8.06 \mathrm{E}-05$ & 0.001254 & -0.023064 & -0.058054 \\
\hline DBS & $0.011052 * * *$ & $0.009963^{* * * *}$ & $0.020517^{* * *}$ & $0.015905 * *$ & $0.098801^{* * *}$ & $0.099426 * * * 74$ \\
\hline SBS & -0.003148 & -0.001767 & -0.005270 & $6.46 \mathrm{E}-05$ & -0.028004 & -0.034562 \\
\hline GOV & -0.018917 & -0.019947 & -0.035421 & -0.040877 & $-0.365267 * *$ & -0.249259 \\
\hline $\mathrm{ROA}_{\mathrm{t}-1} / \mathrm{ROE}_{\mathrm{t}-1 / \mathrm{EPS}_{\mathrm{t}-1} \mathrm{t}}$ & 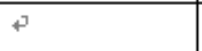 & $-0.201294^{* * *} *$ & 3 & $-0.327332 * 8 *$ & 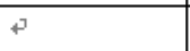 & $-0.161555^{* 8 *}$ \\
\hline Adjust $R^{2}$ & 0.771544 & 0.785142 & 0.623396 & 0.68075 & 0.800929 & 0.806770 \\
\hline
\end{tabular}

Among them, the lagged variables of performance indicators correspond to the dependent variables of the model. $* * * * * *$ means significance level: $0.10,0,05,0.01$

\section{Conclusion}

This paper take listed companies in Beijing as samples, and use the date from 2011 to 2015. Through regression analysis carried on the empirical research for the efficiency of executive monetary incentive and equity incentive efficiency, we find that in the listed companies in Beijing, the monetary compensation incentive and equity incentive have both lagged effect. Monetary compensation incentive can promote the behavior of executives, and is positively correlated with the company's performance. But the effect of previous incentive to the current executive behavior is decreasing as time goes on, so it is more likely to lead to short-term profit behavior. Equity incentive has a positive effect on corporate's performance, and has a positive incentive effect on executives, and the incentive effect does not decrease with the extension of time.

Then the paper controls the natural growth of economy, in order to eliminate the influence of the natural growth of operating result, and the further discusses find that monetary incentive is more effective than equity incentive, which also explains why listed companies in China generally implement monetary compensation incentive system. Based on the above conclusions, we also suggest that the listed companies should pay attention to the supervision in the implementation of monetary compensation incentive and avoid the short-term behavior of executives.

Although the effect of monetary compensation incentive in listed companies of Beijing is more obvious, shareholders cannot ignore the importance of equity incentive as a long-term incentive means. With the improvement of the equity incentive environment of listed companies in our country, the shareholders should begin to gradually implement the equity incentive, and guide the management to pay attention to the growth of long-term value, so as to make the incentive means play a greater role.

\section{Acknowledgement}

This paper gets financial support from Research Innovation Fund for College Students of Beijing University of Posts and Telecommunications. 


\section{References}

[1] Minna Martikainen[. Juha Kinnunen. Antti Miihkinen][. etc]. Board' s financial incentives, competence, and firm risk disclosure Evidence from Finnish index listed companies[J]. Journal of Applied Accounting Research. 2015, 16( 3): 333-358.

[2] Sharon Hannes. Compensating for Executive Compensation: The Case for Gatekeeper Incentive Pay[J]. California Law Review. 2008, 98: 385-437.

[3] Jian Cai[. Kent Cherny. Todd Milbourn]. Compensation and risk incentives in banking and finance[J]. Economic Commentary. 2010.

[4] Gifty Adjei-mensah[. Mohammed Amidu. Joshua Yindenaba Abor]. Executive Compensation, Ownership Structure and Loan Quality of Banks in China[J]. African Development Review. 2015, 27(3): 331-341.

[5] John E. Core[. Wayne R. Guay. David F. Larcker]. Executive Equity Compensation and Incentives: A Survey[J]. FRBNY Economic Policy Review. April 2003, 27-50.

[6] Joseph W. McGuire[. John S. Y. Chiu. Alvar O. Elbing]. Executive Incomes, Sales and Profits[J]. American Economic Association. 2017, 52(4): 753-761.

[7] Rosen. The Conflict Between Managers and Shareholders NBER Working Paper,1992,320-323.

[8] Jensen M[. Murphy K]. Performance Pay and top-management incentive[J].Journal of financial Economics, 1990,98:226-263.

[9] Renjun Zhou [.Kaijuan Gao]. The influence of the controlling rights of large shareholders on the equity incentive effect[J]. Accounting Research. 2012, 5: 50-58.

[10] Junxiong Fang. Executive power and the asymmetry of enterprise compensation[J].

[11] Ling Hu [.Liqin Chen. Sujian Huang]. An empirical analysis of executive compensation, corporate governance and firm performance[J]. Journal of Graduate School of Chinese Academy of Social Sciences.2012, 4: 33-43.

[12] Ping Wang[.Ying Zou. Lifeng Huang]. Core reconstruction of executive compensation incentive: capital cost constraint[J]. China Industrial Economics .2014, 5: 109-121.

[13] Jingjing Zuo[.Yuejun Tang]. Excessive executive compensation incentive: Based on Marginal Diminishing Effect and Chinese Private Listed Companies[J]. Journal of Business Economics.2010, 1: 61-68.

[14] Yu Qin [.Yuanlue Fu. Junping Yang]. Executive compensation incentive should pay attention to distributive justice[J]. Journal of Finance and Economics. 2013, 8: 110-121.

[15] Xi Zhao[.Yupeng Du]. The influence of corporate governance on the sensitivity of executive compensation incentive [J].Ruan Ke Xue. 2009, 11: 92-113.

[16] Xiaorong Li[.Ruijun Zhang]. The impact of equity incentive on risk taking: agency cost or risk aversion [J]. Accounting Research. 2014, 1: 57-95

[17] Hong Luo[.Yongliang Zeng. Baohua Liu]. Executive compensation, corporate governance and Cost Stickiness in state owned enterprises [J]. Economic Survey. 2015, 2: 99-104.

[18] Weian Li[.Xuguang Liu. Jinghan Chen]. Manager ability, corporate governance and contractual reference point: theoretical and Empirical Analysis on determinants of executive compensation in Chinese listed companies [J]. Nankai Business Review. 2010, 2: 4-15. 
[19] Xin Wang[.Yanlin Li. Hongtao Mao]. Enterprise internationalization management, stock price information content and equity incentive effectiveness [J]. Accounting Research. 2014, 11: 46-53.

[20] Jun Chen. Who affected the executive compensation incentive of Listed Companies --Empirical Evidence from Chinese stock market [J].SHANXI CAIJING DAXUE XUEBAO. 2010, 9:70-79.

[21] Huijuan Wang[.Ran Zhang]. Private equity investment and executive compensation contracts of invested enterprises -- Based on the perspective of corporate governance [J].Management World. 2012, 9: 156-167.

[22] Linjie Zhou. Countermeasures to improve the executive compensation incentive system of listed companies [J]. Economic Review. 2013, 5: 91-95.

[23] Junxiong Fang. China's listed companies executives pay sticky [J]. Economic Research Journal. 2009, 3: 110-124.

[24] Juan Zhang[.Zhizhong Huang]. Heterogeneity of earnings management, corporate governance and executive compensation: An Empirical Study Based on Chinese listed companies [J]. Economic Management Journal. 2014, 9: 79-90.

[25] Song Tang[.Zheng Sun]. Political connections, executive compensation and corporate performance [J]. Management World. 2014, 5: 93-188.

[26] Hui Zhou[.Rui Ma. Jiuhua Zhu]. Executive compensation incentive and earnings management of Chinese state owned listed companies [J]. The Theory and Practice of Finance and Economics. 2010, 4: 48-52.

[27] Chang Song[.Yiqing Zhao]. A study on the incentive effect of executive compensation of Listed Companies in China [J]. Commercial Research. 2011, 5: 72-77.

[28] Baicheng Zhou[.Beixing Wang]. A study on the relationship among corporate governance, performance and executive compensation in Chinese listed companies [J]. Journal Of Applied Statistics and Management. 2007, 4: 669-675.

[29] Junxiong Fang. Executive compensation and corporate governance [J]. Management World. 2012, 11: 144-155.

[30] Liang Qu[.Guoliang Ren]. Empirical research on the relationship between executive compensation incentive, equity incentive and corporate value [J]. Modern Economic Science. 2010, 5: 73-80.

[31] Gang Wei. Senior management incentive and performance of listed companies [J]. Economic Research Journal. 2000, 3: 32-80.

[32] Ting Lei [.Jianan Zhou]. Equity incentive salary gap _ executives and equity capital cost [J]. Journal of Management Sciences. 2014, 11: 12-26.

[33] Wenlong Zong [.Yutao Wang. Zi Wei]. Equity incentive can retain executives do _ empirical evidence China stock market based on [J]. Accounting Research. 2013, 9: 58-63.

[34] Dapang Lin [.Dongwei Su]. Equity incentive and corporate performance_based on the new research perspective of earnings management [J]. Journal of Financial Research. 2011, 9: 162-177.

[35] Jianan Cao [.Lei Nie. Shan Li]. Empirical Study on the relationship between executive stock ownership incentive and corporate performance of listed companies [J]. China Economist. 2013, 1:71-78. 
[36] Changjiang Lv [.Mingzhu Yan. Huilian Zheng]. Why listed companies choose equity incentive plan [J]. Accounting Research. 2011, 1: 68-96.

[37] Bin Gu [.Liye Zhou]. Study on the effect of equity incentive of Listed Companies in China [J]. Accounting Research. 2007, 2: 79-92.

[38] Yuhui Wu[.Shinong Wu]. Executive compensation: motivation or self-interest? --Evidence from Chinese listed companies [J]. Accounting Research. 2010,11

[39] Zengquan Li. Incentive mechanism and firm performance: An Empirical Study Based on listed companies [J]. Accounting Research.2001.01

[40] Fusheng Yu[.Ying Zhang].On Economic Problems. [J]. Pay gap and Earnings managemen:.2013.04:112-117

[41] Hou Jianping[.Hui Rong]. Finance and accouting mounthly. [J]. Dynamic Endogeneity of Executive Incentive and Earnings anagement in Manufacturing Listed Companies:.2014.09:09-13 